\title{
The complete genome sequence of the rumen methanogen Methanobacterium formicicum BRM9
}

\author{
William J Kelly ${ }^{1}$, Sinead C Leahy ${ }^{1,2^{*}}$, Dong Li ${ }^{1}$, Rechelle Perry', Suzanne C Lambie ${ }^{1}$, Graeme T Attwood ${ }^{1,2}$ \\ and Eric Altermann ${ }^{1,3^{*}}$
}

\begin{abstract}
Methanobacterium formicicum BRM9 was isolated from the rumen of a New Zealand Friesan cow grazing a ryegrass/ clover pasture, and its genome has been sequenced to provide information on the phylogenetic diversity of rumen methanogens with a view to developing technologies for methane mitigation. The $2.45 \mathrm{Mb}$ BRM9 chromosome has an average $\mathrm{G}+\mathrm{C}$ content of $41 \%$, and encodes 2,352 protein-coding genes. The genes involved in methanogenesis are comparable to those found in other members of the Methanobacteriaceae with the exception that there is no [Fe]-hydrogenase dehydrogenase ( $\mathrm{Hmd}$ ) which links the methenyl-H4MPT reduction directly with the oxidation of $\mathrm{H}_{2}$. Compared to the rumen Methanobrevibacter strains, BRM9 has a much larger complement of genes involved in determining oxidative stress response, signal transduction and nitrogen fixation. BRM9 also has genes for the biosynthesis of the compatible solute ectoine that has not been reported to be produced by methanogens. The BRM9 genome has a prophage and two CRISPR repeat regions. Comparison to the genomes of other Methanobacterium strains shows a core genome of $\sim 1,350$ coding sequences and 190 strain-specific genes in BRM9, most of which are hypothetical proteins or prophage related.
\end{abstract}

Keywords: Methanogen, Methane, Ruminant, Methanobacterium formicicum

\section{Introduction}

Ruminants have evolved an efficient digestive system in which microbes ferment the plant material that constitutes the animal's diet to produce short chain fatty acids, principally acetic, propionic and butyric acids, and other products [1]. This fermentation is carried out by a complex microbial community which includes bacteria, ciliate protozoa, anaerobic fungi, and methanogenic archaea, and has been the focus of numerous studies. The role of the methanogenic archaea in the rumen environment is important as they use hydrogen $\left(\mathrm{H}_{2}\right)$ derived from microbial fermentation as their energy source and combine it with carbon dioxide $\left(\mathrm{CO}_{2}\right)$ to form methane $\left(\mathrm{CH}_{4}\right)$, which is belched from the animal and released to the atmosphere. Other fermentation end-products including formate and methyl-containing compounds can also be substrates for methanogenesis [2].

\footnotetext{
* Correspondence: sinead.leahy@agresearch.co.nz; eric.altermann@agresearch. co.nz

'Rumen Microbiology, Animal Nutrition and Health, AgResearch Limited, Grasslands Research Centre, Tennent Drive, Private Bag 11008, Palmerston North 4442, New Zealand

Full list of author information is available at the end of the article
}

Methane is a potent greenhouse gas contributing to global climate change, and ruminant derived $\mathrm{CH}_{4}$ accounts for about one quarter of all anthropogenic $\mathrm{CH}_{4}$ emissions [3]. Development of strategies to reduce $\mathrm{CH}_{4}$ emissions from farmed animals are currently being investigated, and methanogen genome sequence information has already been used to inform $\mathrm{CH}_{4}$ mitigation strategies based on vaccines and small-molecule inhibitors $[4,5]$. $\mathrm{CH}_{4}$ mitigation technologies should target features that are conserved across all rumen methanogens, and be methanogen-specific so that other rumen microbes can continue their normal digestive functions. To address this we are sequencing the genomes of cultures that represent the phylogenetic diversity of rumen methanogens to define their conserved features as targets for developing $\mathrm{CH}_{4}$ mitigation technologies $[4,6,7]$, and to understand their role in the rumen environment, and interactions with other members of the rumen microbiome. 


\section{Organism information}

Methanobacterium sp. BRM9 was isolated from the rumen of a New Zealand Friesan cow grazing a ryegrass/ clover pasture [8]. It was described as a Gram positive non-motile, short rod which becomes a long, irregular rod at later growth stages. It is able to grow and produce methane from formate and $\mathrm{H}_{2} / \mathrm{CO}_{2}$, but not from acetate, alcohols or methylamines. Growth occurred over a wide temperature range $\left(25-45^{\circ} \mathrm{C}\right)$ and at $\mathrm{pH} 6-8$. Rumen fluid was required for growth. The $16 \mathrm{~S}$ rRNA from BRM9 is 99.8\% similar to the M. formicicum type strain DSM 1535 [Figure 1] which was isolated from a sewage sludge digester $[9,10]$ and as such BRM9 can be considered as a strain of M. formicicum. M. formicicum is found at high densities in anaerobic digesters and freshwater sediments, and has previously been isolated from the rumen [11], although Methanobacterium species only occur at low density in this environment [2]. Isolates have also been obtained as endosymbionts of anaerobic amoebae and ciliate protozoa species. Electron microscopic studies of $M$. formicicum show a long rod shaped morphology, and cells characterized by numerous cytoplasmic membrane bodies believed to be formed by invagination of the cell membrane $[12,13]$. Characteristics of M. formicicum BRM9 are shown in Table 1 and Additional file 1: Table S1.

\section{Genome sequencing information \\ Genome project history}

Methanobacterium formicicum BRM9 was selected for genome sequencing on the basis of its phylogenetic position relative to other methanogens belonging to the family Methanobacteriaceae. Table 2 presents the project information and its association with MIGS version 2.0 compliance [27].

\section{Growth conditions and DNA isolation}

BRM9 was grown in BY medium [28] with added SL10 Trace Elements solution (1 ml added $\mathrm{l}^{-1}$ ) [29], Selenite/ Tungstate solution (final concentration of selenite and tungstate are 3 and $4 \mu \mathrm{g} \mathrm{l}^{-1}$ respectively), [30] and Vitamin 10 solution $(0.1 \mathrm{ml}$ added to $10 \mathrm{ml}$ culture before inoculation) [6]. $\mathrm{H}_{2}$ was supplied as the energy source by pumping the culture vessels to $180 \mathrm{kPa}$ over pressure with an 80:20 mixture of $\mathrm{H}_{2}: \mathrm{CO}_{2}$. Genomic DNA was extracted from freshly grown cells using a modified version of a liquid $\mathrm{N}_{2}$ and grinding method [31]. Briefly, BRM9 cultures were harvested by centrifugation at $20,000 \times g$ for $20 \mathrm{~min}$ at $4^{\circ} \mathrm{C}$ and cell pellets combined into $40 \mathrm{ml}$ Oakridge centrifuge tubes and frozen at $-80^{\circ} \mathrm{C}$. The frozen cell pellets were placed in a sterile, pre-cooled $\left(-85^{\circ} \mathrm{C}\right)$ mortar and ground to a powder with periodic addition of liquid $\mathrm{N}_{2}$.

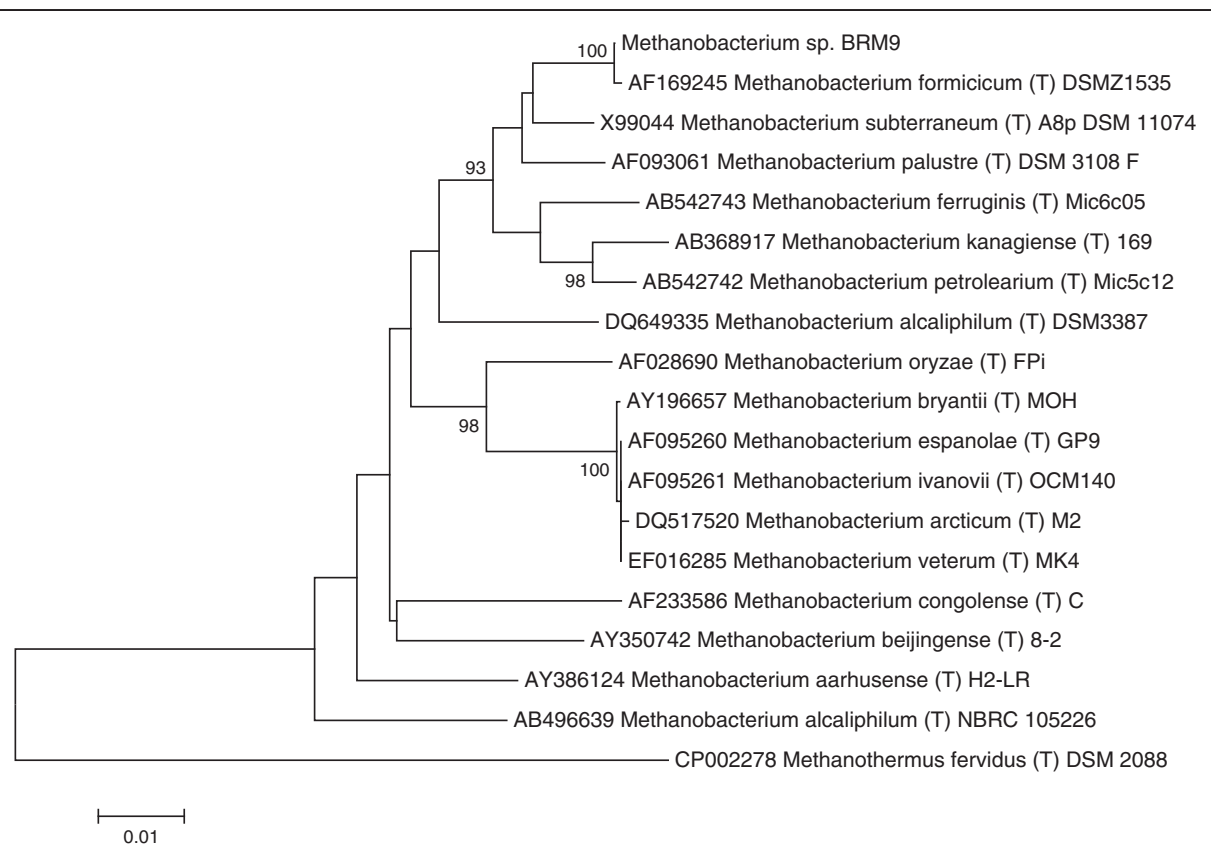

Figure 1 Phylogenetic tree showing the position of Methanobacterium sp. BRM9 relative to type strains of other Methanobacterium species. The strains and their corresponding accession numbers are shown. The evolutionary history was inferred using the Neighbor-Joining method [14] with Methanothermus fervidus used as an outgroup. The optimal tree with the sum of branch length $=0.34833139$ is shown. The percentage of replicate trees $(>90 \%)$ in which the associated taxa clustered together in the bootstrap test (1000 replicates) are shown next to the branches [15]. The tree is drawn to scale, with branch lengths in the same units as those of the evolutionary distances used to infer the phylogenetic tree. The evolutionary distances were computed using the Kimura 2-parameter method [16] and are in the units of the number of base substitutions per site. The analysis involved 19 nucleotide sequences. All positions containing gaps and missing data were eliminated. There were a total of 1168 positions in the final dataset. Evolutionary analyses were conducted in MEGA5 [17]. 
Table 1 Classification and general features of Methanobacterium formicicum BRM9

\begin{tabular}{|c|c|c|c|}
\hline MIGS ID & Property & Term & Evidence code $^{\mathrm{a}}$ \\
\hline & Current classification & Domain: Archaea & TAS [18] \\
\hline & & Phylum: Euryarchaeota & TAS [19] \\
\hline & & Class: Methanobacteria & TAS $[20,21]$ \\
\hline & & Order: Methanobacteriales & TAS [22-24] \\
\hline & & Family: Methanobacteriaceae & TAS [25] \\
\hline & & Genus: Methanobacterium & TAS [23] \\
\hline & & Species: Methanobacterium formicicum strain BRM9 & TAS [8] \\
\hline & Gram stain & Positive & TAS [8] \\
\hline & Cell shape & Rod & TAS [8] \\
\hline & Motility & No & TAS [8] \\
\hline & Sporulation & No & IDA \\
\hline & Temperature range & $25-45^{\circ} \mathrm{C}$ & TAS [8] \\
\hline & Optimum temperature & $38^{\circ} \mathrm{C}$ & TAS [8] \\
\hline & Carbon source & $\mathrm{CO}_{2}$, Acetate & IDA \\
\hline & Energy source & $\mathrm{H}_{2}+\mathrm{CO}_{2}$, formate & TAS [8] \\
\hline & Terminal electron receptor & $\mathrm{CO}_{2}$ & IDA \\
\hline MIGS-6 & Habitat & Bovine rumen & TAS [8] \\
\hline MIGS-6.3 & Salinity & not reported & \\
\hline MIGS-22 & Oxygen & Strict anaerobe & IDA \\
\hline MIGS-15 & Biotic relationship & Symbiont of ruminants & TAS [8] \\
\hline MIGS-14 & Pathogenicity & Not known as a pathogen & NAS \\
\hline MIGS-4 & Geographic location & Palmerston North, New Zealand & IDA \\
\hline MIGS-5 & Sample collection time & Not reported & \\
\hline MIGS-4.1 & Latitude & Latitude: $-40.35\left(40^{\circ} 21^{\prime} 00^{\prime \prime S}\right)$ & IDA \\
\hline MIGS-4.2 & Longitude & Longitude: +175.61 (175³6'36"E) & IDA \\
\hline MIGS-4.3 & Depth & Not reported & \\
\hline MIGS-4.4 & Altitude & $30 \mathrm{~m}$ & IDA \\
\hline
\end{tabular}

a Evidence codes - TAS: Traceable Author Statement; IDA: Inferred from Direct Assay; NAS: Non-traceable Author Statement (i.e., not directly observed for the living, isolated sample, but based on a generally accepted property for the species, or anecdotal evidence) [26].

Table 2 Project information

\begin{tabular}{lll}
\hline MIGS ID & Property & Term \\
\hline MIGS-31 & Finishing quality & high-quality, closed genome \\
MIGS-28 & Libraries used & 3 Kb mate paired-end library \\
MIGS-29 & Sequencing platforms & 454 GS FLX, Titanium chemistry \\
MIGS-31.2 & Fold coverage & $97 x$ \\
MIGS-30 & Assemblers & Newbler \\
MIGS-32 & Gene calling method & Glimmer and BLASTX \\
& Genome Database release & October 2, 2014 \\
& Genbank ID & CP006933 \\
& Genbank Date of Release & October 2, 2014 \\
& GOLD ID & Gp0007264 \\
& Project relevance & Ruminant methane emissions \\
\hline
\end{tabular}

Buffer B1 (5 ml Qiagen Genomic-Tip 500 Maxi kit, Qiagen, Hilden, Germany) containing RNase $\left(2 \mu \mathrm{g} \mathrm{ml}^{-1}\right.$ final concentration) was added to the powdered cell pellet to create a slurry which was then removed to a $15 \mathrm{ml}$ Falcon tube. An additional $6 \mathrm{ml}$ of $\mathrm{B} 1$ buffer was used to rinse the remaining material from the mortar and pestle and combined with the cell slurry, which was then treated following the Qiagen Genomic-Tip 500/G Maxi kit instructions. Finally, the genomic DNA was precipitated by the addition of 0.7 vol isopropanol, and collected by centrifugation at $12,000 \times g$ for $10 \mathrm{~min}$ at room temperature. The supernatant was removed, and the DNA pellet was washed in 70\% ethanol, re-dissolved in TE buffer $(10 \mathrm{mM}$ Tris- $\mathrm{HCl}, 1 \mathrm{mM}$ EDTA $\mathrm{pH}$ 7.5) and stored at $-20^{\circ} \mathrm{C}$ until required.

\section{Genome sequencing and assembly}

The complete genome sequence of BRM9 was determined using pyrosequencing of $3 \mathrm{~Kb}$ mate paired-end 
Table 3 Summary of genome

\begin{tabular}{llll}
\hline Label & Size $(\mathbf{M b})$ & Topology & INSDC identifier \\
\hline Chromosome & 2.45 & Circular & CP006933 \\
\hline
\end{tabular}

sequence libraries using a 454 GS FLX platform with Titanium chemistry (Macrogen, Korea). Pyrosequencing reads provided $97 \times$ coverage of the genome and were assembled using the Newbler assembler version 2.0 (Roche 454 Life Sciences, USA). The Newbler assembly resulted in 85 contigs across 9 scaffolds. Gap closure was managed using the Staden package [32] and gaps were closed using additional Sanger sequencing by standard and inverse PCR based techniques. A total of 219 additional reactions were used to close gaps and to improve the quality of the genome sequence to ensure correct assembly and to resolve any remaining base-conflicts. Assembly validation was confirmed by pulsed-field gel electrophoresis as described previously [6], using the enzyme AscI which cuts the BRM9 chromosome at 6 sites.

\section{Genome annotation}

A GAMOLA/ARTEMIS [33,34] software suite was used to manage genome annotation. Protein-encoding open reading frames (ORFs) were identified using the ORFprediction program Glimmer [35] and BLASTX [36,37]. A manual inspection was performed to verify or, if necessary, redefine the start and stop codons of each ORF. Assignment of protein function to ORFs was performed manually using results from the following sources; BLASTP [36] to both a non-redundant protein database provided by the National Centre for Biotechnology Information (NCBI) [38] and Clusters of Orthologous Groups (COG) database [39]. HMMER [40] was used to identify protein

Table 4 Nucleotide content and gene count levels of the genome

\begin{tabular}{|c|c|c|}
\hline \multirow[t]{2}{*}{ Attribute } & \multicolumn{2}{|c|}{ Genome (total) } \\
\hline & Value & $\%$ of total ${ }^{a}$ \\
\hline Size (bp) & $2,449,987$ & 100.00 \\
\hline $\mathrm{G}+\mathrm{C}$ content $(\mathrm{bp})$ & $1,012,813$ & 41.34 \\
\hline Coding region (bp) & $2,028,429$ & 82.79 \\
\hline Total genes $^{b}$ & 2,418 & 100.00 \\
\hline RNA genes & 52 & 2.15 \\
\hline Protein-coding genes & 2352 & 97.27 \\
\hline Genes assigned to COGs & 1,715 & 70.93 \\
\hline Genes with signal peptides & 95 & 3.93 \\
\hline Genes with transmembrane helices & 573 & 23.70 \\
\hline
\end{tabular}

motifs to both the PFAM [41] and TIGRFAM [42] libraries. TMHMM $[43,44]$ was used to predict transmembrane sequences, and SignalP, version 4.1 [45] was used for the prediction of signal peptides. Ribosomal RNA genes were detected on the basis of BLASTN searches to a custom GAMOLA ribosomal database. Transfer RNA genes were identified using tRNAscan-SE [46]. Miscellaneous-coding RNAs were identified using the Rfam database [47] utilizing the INFERNAL software package [48]. The genome sequence was prepared for NCBI submission using Sequin [49]. The adenine residue of the start codon of the Cdc6-1 replication initiation protein (BRM9_0001) gene was chosen as the first base for the BRM9 genome. The nucleotide sequence of the Methanobacterium formicicum BRM9 chromosome has been deposited in Genbank under accession number CP006933.

Table $\mathbf{5}$ Number of genes associated with the $\mathbf{2 5}$ general COG functional categories

\begin{tabular}{|c|c|c|c|}
\hline Code & Value & $\%$ of total ${ }^{a}$ & Description \\
\hline J & 148 & 6.29 & Translation \\
\hline A & 1 & 0.04 & RNA processing and modification \\
\hline K & 104 & 4.42 & Transcription \\
\hline$L$ & 93 & 3.95 & Replication, recombination and repair \\
\hline$B$ & 4 & 0.17 & Chromatin structure and dynamics \\
\hline $\mathrm{D}$ & 10 & 0.42 & Cell cycle control, mitosis and meiosis \\
\hline Y & - & - & Nuclear structure \\
\hline V & 37 & 1.57 & Defense mechanisms \\
\hline $\mathrm{T}$ & 72 & 3.06 & Signal transduction mechanisms \\
\hline M & 64 & 2.72 & Cell wall/membrane biogenesis \\
\hline $\mathrm{N}$ & 5 & 0.21 & Cell motility \\
\hline Z & - & - & Cytoskeleton \\
\hline W & - & - & Extracellular structures \\
\hline$U$ & 13 & 0.55 & Intracellular trafficking and secretion \\
\hline $\mathrm{O}$ & 55 & 2.34 & $\begin{array}{l}\text { Posttranslational modification, } \\
\text { protein turnover, chaperones }\end{array}$ \\
\hline C & 187 & 7.95 & Energy production and conversion \\
\hline G & 51 & 2.17 & Carbohydrate transport and metabolism \\
\hline$E$ & 121 & 5.14 & Amino acid transport and metabolism \\
\hline $\mathrm{F}$ & 50 & 2.12 & Nucleotide transport and metabolism \\
\hline $\mathrm{H}$ & 93 & 3.95 & Coenzyme transport and metabolism \\
\hline I & 30 & 1.27 & Lipid transport and metabolism \\
\hline P & 92 & 3.91 & Inorganic ion transport and metabolism \\
\hline Q & 26 & 1.10 & $\begin{array}{l}\text { Secondary metabolites biosynthesis, } \\
\text { transport and catabolism }\end{array}$ \\
\hline $\mathrm{R}$ & 270 & 11.47 & General function prediction only \\
\hline S & 189 & 8.04 & Function unknown \\
\hline- & 637 & 27.08 & Not in COGs \\
\hline
\end{tabular}

a The total is based on the total number of protein coding genes in the annotated genome. 
Table 6 Genomes of Methanobacterium species from various anaerobic environments

\begin{tabular}{|c|c|c|c|c|c|c|}
\hline Species & Isolation source & Genome size $(\mathrm{Mb})$ & Accession \# & CDS & $\%$ GC & Reference \\
\hline Methanobacterium formicicum BRM9 & Bovine rumen & 2.45 & CP006933 & 2,352 & 41 & This report \\
\hline Methanobacterium formicicum PP1 (DSM3637) & Free-living amoeba endosymbiont & $\sim 2.68$ & AMPO00000000 & 2,519 & 38 & {$[57]$} \\
\hline Methanobacterium sp. Maddingley MBC34 & Coal seam formation water & $\sim 2.42$ & AMGN00000000 & 2,411 & 39 & {$[58]$} \\
\hline Methanobacterium lacus AL-21 & Peatland [59] & 2.58 & CP002551 & 2,533 & 36 & \\
\hline Methanobacterium paludis SWAN-1 & Peatland [59] & 2.55 & CP002772 & 2,442 & 36 & \\
\hline Methanobacterium sp. Mb1 & Biogas plant & 2.03 & HG425166 & 2,021 & 40 & [60] \\
\hline
\end{tabular}

\section{Genome properties}

The genome of Methanobacterium formicicum BRM9 consists of a single 2,449,988 basepair (bp) circular chromosome with an average $\mathrm{G}+\mathrm{C}$ content of $41 \%$. A total of 2,418 genes were predicted, 2,352 of which were proteincoding genes, representing $83 \%$ of the total genome sequence. A putative function was assigned to 1,715 of the protein-coding genes, with the remainder annotated as hypothetical proteins. The properties and statistics of the genome are summarized in Tables 3, 4 and 5. The BRM9 genome has a $37 \mathrm{~Kb}$ prophage (BRM9_1642-1689) with several genes that have best matches to those from other prophage. The phage ORFs are flanked by 22 bp sequences indicative of attL and attR sites. In addition there are several CRISPR genes associated with two CRISPR repeat regions of 7178 and $11914 \mathrm{bp}$, as well as the components of a type I restriction-modification system.

\section{Insights from the genome}

The genes involved in methanogenesis are comparable to those found in other members of the Methanobacteriaceae

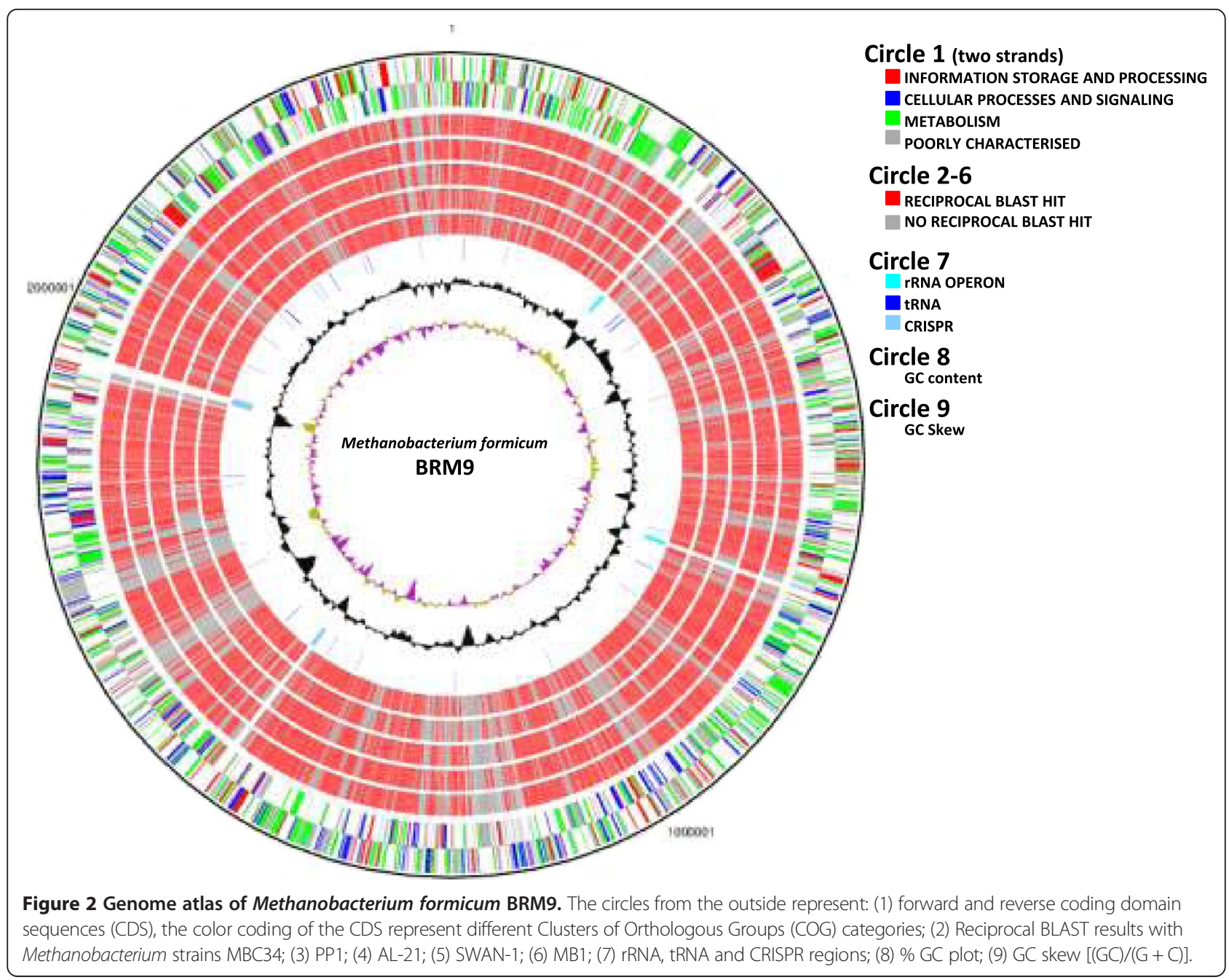




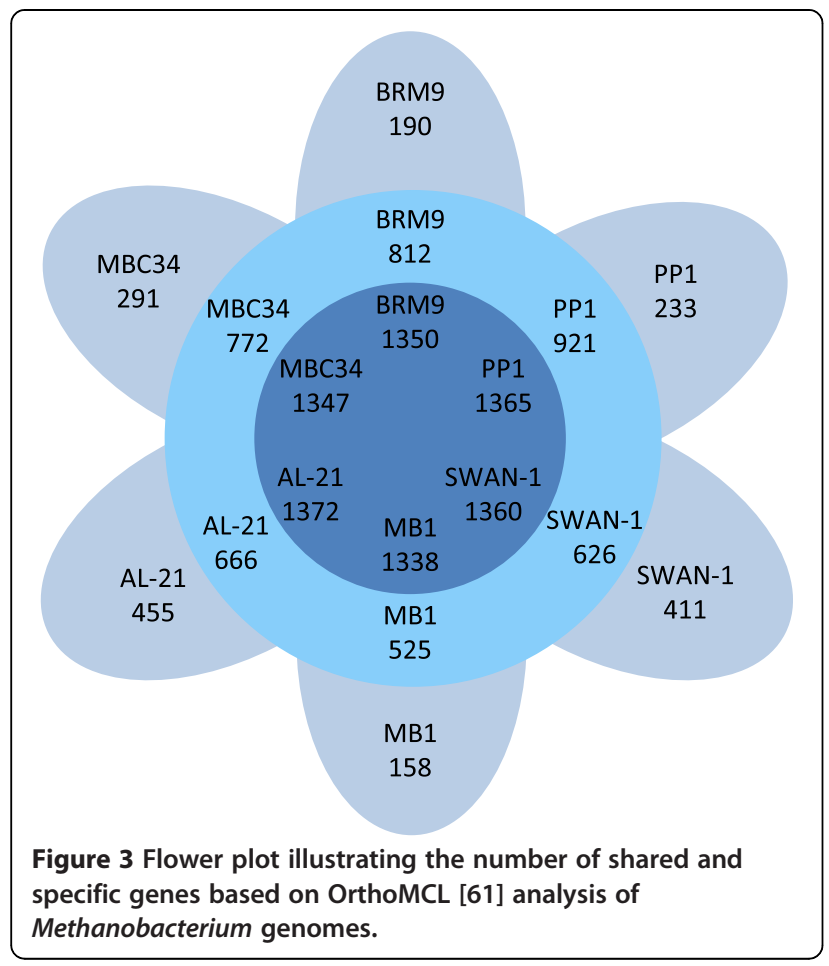

with the exception that there is no [Fe]-hydrogenase dehydrogenase (Hmd) which links the methenyl-H4MPT reduction directly with the oxidation of $\mathrm{H}_{2}$. BRM9 has the methyl coenzyme $\mathrm{M}$ reductase II genes (mrtAGDB, BRM9_2153-2156), unlike Methanobrevibacter strains M1 and AbM4 [6,7]. BRM9 has a cysteinyl-tRNA synthetase (cysS), but also encodes the alternative tRNA-dependent cysteine biosynthesis pathway (sepS/pscS) found in Methanocaldococcus jannaschii and other methanogens [50] but not in Methanobrevibacter sp. BRM9 also has a carbon monoxide dehydrogenase/acetyl-coenzyme A synthase (CODH/ACS, or Cdh) to fix $\mathrm{CO}_{2}$ and form acetyl-CoA, and several acetyl-CoA synthetases one of which is located next to a possible acetate permease (BRM9_1255). Like many other methanogens, the CODH/ACS genes in BRM9 are found in a single cluster (BRM9_0795-0801). There is also a NAD-dependent malic enzyme (BRM9_2358) able to catalyse the oxidative decarboxylation of malate to form pyruvate and $\mathrm{CO}_{2}$. This is found in three other Methanobacterium strains (MBC34, PP1, SWAN-1) but not in other members of the Methanobacteriaceae.

The cell walls of members of the Methanobacteriaceae consist of pseudomurein and while the pathway for pseudomurein biosynthesis and its primary structure have been elucidated the enzymes involved have not been characterized. The predicted pseudomurein biosynthesis genes are similar to those found in Methanobrevibacter species [6], but there are differences in the other cell wall glycopolymers. BRM9 has several proteins with multiple copies of the PMBR domain (Pfam accession
PF09373) predicted to be involved in binding to pseudomurein. There are four clusters of genes involved in polysaccharide biosynthesis and two oligosaccharyl transferases, but BRM9 does not have homologues of neuA/neuB found in other methanogen strains including $M$. formicicum DSM 3637 [51]. BRM9 has fewer cell surface proteins than do Methanobrevibacter species, and these contain a range of different repeat domains.

Compared to the rumen Methanobrevibacter species BRM9 has a much larger complement of activities involved in oxidative stress response with a superoxide dismutase, a catalase/peroxidase and a peroxiredoxin (alkyl hydroperoxide reductase). BRM9 also has the three ectoine biosynthetic genes (ectABC, BRM9_2205-2207) that encode production of the compatible solute ectoine that is normally found in halophilic or halotolerant organisms but has not been reported to be produced by methanogens [52]. The ectoine biosynthetic genes in BRM9 show no BLAST matches to other methanogens but have significant matches to Dehalogenimonas lykanthroporepellens, a dehalogenating bacterium from the phylum Chloroflexi isolated from contaminated groundwater [53]. The ect $\mathrm{B}$ and ect $\mathrm{C}$ genes also show homology to those from the rumen bacterium Wolinella succinogenes. Unlike the Methanobrevibacter species BRM9 has a large number of genes encoding components of histidine kinase/response regulator signal transduction systems. Many of these proteins include 1-5 PAS domains. These are believed to monitor changes in redox potential, oxygen, and the overall energy level of the cell [54].

The metabolism of nitrogen by BRM9 is somewhat different from Methanobrevibacter M1 and AbM4. BRM9 has two ammonium transporters and encodes the glutamine synthase (GS)/glutamate synthase (glutamine:2-oxoglutarate aminotransferase, GOGAT) pathway of ammonium assimilation. Methanobacterium formicicum has been reported to fix nitrogen [55] and BRM9 contains a nif operon similar to that found in Methanococcus maripaludis and composed of nitrogenase and nitrogenase cofactor biosynthesis genes. Nitrogen assimilation genes are regulated by NrpR which represses transcription of nitrogen fixation genes, glutamine synthase, ammonium transporters and some other genes in M. maripaludis [56]. NrpR binds to inverted repeat operators in the promoter regions of these genes. The inverted repeat sequence recognized is GGAAN6TTCC and occurs in BRM9 upstream from the starts of $g \ln \mathrm{A}$, nif $\mathrm{H}, p d x \mathrm{~T}$, amt 1 and $a m t 2$.

The genome of $M$. formicicum BRM9 is compared with those of other sequenced methanogens from the genus Methanobacterium in Table 6. The genome atlas of M. formicicum BRM9 is shown in Figure 2 and indicates that the gene content of these Methanobacterium strains is highly similar. Comparison of the ORFeome of BRM9 with those of other sequenced Methanobacterium species 
[Figure 3] shows a core genome of $\sim 1,350$ genes. There are 190 strain-specific genes in BRM9, which include the ectoine biosynthesis genes, CRISPR and prophage-related genes as well as numerous hypothetical proteins.

\section{Conclusions}

This is the first report of a genome sequence for a Methanobacterium formicicum strain of rumen origin. The genus Methanobacterium consists of mesophilic methanogens from diverse anaerobic environments, but they only constitute a small proportion of the methanogen diversity in the rumen. However, the similarity in gene content between BRM9 and strains from other environments implies that BRM9 is not particularly adapted to the rumen and may struggle in competition with the better adapted Methanobrevibacter species. The conserved nature of the M. formicicum BRM9 genes for methanogenesis, central metabolism and pseudomurein cell wall formation suggest that this species will be amenable to inhibition by the small molecule inhibitor and vaccine-based methane mitigation technologies that are being developed for the other genera of methanogens found in the rumen.

\section{Additional file}

\section{Additional file 1: Table S1. Associated MIGS record.}

\section{Competing interests}

The authors declare that they have no competing interests.

\section{Authors' contributions}

WJK, SCL, GTA, EA conceived and designed the experiments. SCL, DL, RP, SCLa performed the sequencing and assembly experiments. WJK, SCL, EA performed the annotation and comparative studies. WJK, SCL wrote the manuscript. All authors commented on the manuscript before submission. All authors read and approved the final manuscript.

\section{Acknowledgements}

The BRM9 genome sequencing project was funded by the New Zealand Pastoral Greenhouse Gas Research Consortium.

\section{Author details}

'Rumen Microbiology, Animal Nutrition and Health, AgResearch Limited, Grasslands Research Centre, Tennent Drive, Private Bag 11008, Palmerston North 4442, New Zealand. ${ }^{2}$ New Zealand Agricultural Greenhouse Gas Research Centre, Grasslands Research Centre, Tennent Drive, Private Bag 11008, Palmerston North 4442, New Zealand. ${ }^{3}$ Riddet Institute, Massey University, Palmerston North 4442, New Zealand.

\section{Received: 16 June 2014 Accepted: 29 October 2014}

Published: 8 December 2014

\section{References}

1. Clauss M, Hume ID, Hummel J. Evolutionary adaptations of ruminants and their potential relevance for modern production systems. Animal. 2010; 4:979-92.

2. Janssen PH, Kirs M. Structure of the archaeal community of the rumen. Appl Environ Microbiol. 2008; 74:3619-25.

3. Thorpe A. Enteric fermentation and ruminant eructation: the role (and control?) of methane in the climate change debate. Climate Change. 2009; 93:407-31.

4. Leahy SC, Kelly WJ, Ronimus RS, Wedlock N, Altermann E, Attwood GT. Genome sequencing of rumen bacteria and archaea and its application to methane mitigation strategies. Animal. 2013; 7(Suppl 2):235-43.
5. Wedlock N, Janssen PH, Leahy S, Shu D, Buddle BM. Progress in the development of vaccines against rumen methanogens. Animal. 2013; 7(Suppl 2):244-52.

6. Leahy SC, Kelly WJ, Altermann E, Ronimus RS, Yeoman CJ, Pacheco DM, Li D, Kong Z, McTavish S, Sang C, Lambie SC, Janssen PH, Dey D, Attwood GT. The genome sequence of the rumen methanogen Methanobrevibacter ruminantium reveals new possibilities for controlling ruminant methane emissions. PLoS One. 2010; 5:e8926.

7. Leahy SC, Kelly WJ, Li D, Li Y, Altermann E, Lambie SC, Cox F, Attwood GT. The complete genome sequence of Methanobrevibacter sp. AbM4. Stand Genomic Sci. 2013; 8:215-27.

8. Jarvis GN, Strömpl C, Burgess DM, Skillman LC, Moore ERB, Joblin KN. Isolation and identification of ruminal methanogens from grazing cattle. Curr Microbiol. 2000; 40:327-32.

9. Bryant MP, Boone DR. Isolation and characterization of Methanobacterium formicicum MF. Int J Syst Bacteriol. 1987; 37:171.

10. Boone DR. Replacement of the type strain of Methanobacterium formicicum and reinstatement of Methanobacterium bryantii sp. nov. nom. rev. (ex Balch and Wolfe, 1981) with M.o.H. (DSM 863) as the type strain. Int J Syst Bacteriol. 1987; 37:172-73

11. Oppermann RA, Nelson WO, Brown RE. In vitro studies of methanogenic rumen bacteria. J Dairy Sci. 1957; 40:779-88.

12. Langenberg KF, Bryant MP, Wolfe RS. Hydrogen-oxidizing methane bacteria II. Electron microscopy. J Bacteriol. 1968; 95:1124-29.

13. Zeikus JG, Bowen VG. Comparative ultrastructure of methanogenic bacteria. Can J Microbiol. 1975; 21:121-29.

14. Saitou N, Nei M. The neighbor-joining method: A new method for reconstructing phylogenetic trees. Mol Biol Evol. 1987; 4:406-25.

15. Felsenstein J. Confidence limits on phylogenies: An approach using the bootstrap. Evolution. 1985; 39:783-91.

16. Kimura M. A simple method for estimating evolutionary rate of base substitutions through comparative studies of nucleotide sequences. J Mol Evol. 1980; 16:111-20.

17. Tamura K, Peterson D, Peterson N, Stecher G, Nei M, Kumar S. MEGA5: molecular evolutionary genetics analysis using maximum likelihood, evolutionary distance, and maximum parsimony methods. Mol Biol Evol. 2011; 28:2731-39.

18. Woese $C R$, Kandler $O$, Wheelis ML. Towards a natural system of organisms: proposal for the domains Archaea, Bacteria, and Eucarya. Proc Natl Acad Sci U S A. 1990; 87:4576-79.

19. Garrity GM, Phylum HJG, All. Euryarchaeota phy. nov. In: Garrity GM, Boone DR, Castenholz RW, editors. Bergey's Manual of Systematic Bacteriology, Volume 1. 2nd ed. New York: Springer; 2001: p. 211-355.

20. Validation List no. 85. Validation of publication of new names and new combinations previously effectively published outside the IJSEM. Int J Syst Evol Microbiol. 2002; 52:685-90.

21. Boone DR, Class I. Methanobacteria class. nov. In: Garrity GM, Boone DR, Castenholz RW, editors. Bergey's Manual of Systematic Bacteriology, Volume 1. 2nd ed. New York: Springer; 2001: p. 213-34.

22. List Editor. Validation List no. 6. Validation of the publication of new names and new combinations previously effectively published outside the IJSB. Int J Syst Bacteriol. 1981; 31:215-18.

23. Balch WE, Fox GE, Magrum LJ, Woese CR, Wolfe RS. Methanogens: reevaluation of a unique biological group. Microbiol Rev. 1979; 43:260-96.

24. Judicial Commission of the International Committee on Systematics of Prokaryotes. The nomenclatural types of the orders Acholeplasmatales, Halanaerobiales, Halobacteriales, Methanobacteriales, Methanococcales, Methanomicrobiales, Planctomycetales, Prochlorales, Sulfolobales, Thermococcales, Thermoproteales and Verrucomicrobiales are the genera Acholeplasma, Halanaerobium, Halobacterium, Methanobacterium, Methanococcus, Methanomicrobium, Planctomyces, Prochloron, Sulfolobus, Thermococcus, Thermoproteus and Verrucomicrobium, respectively. Opinion 79. Int J Syst Evol Microbiol. 2005; 55:517-18.

25. Skerman VBD, McGowan V, Sneath PHA. Approved Lists of Bacterial Names. Int J Syst Bacteriol. 1980; 30:225-420.

26. Ashburner M, Ball CA, Blake JA, Botstein D, Butler H, Cherry JM, Davis AP, Dolinski K, Dwight SS, Eppig JT, Harris MA, Hill DP, Issel-Tarver L, Kasarskis A, Lewis S, Matese JC, Richardson JE, Ringwald M, Rubin GM, Sherlock G. Gene Ontology: tool for the unification of biology. Nat Genet. 2000; 25:25-9.

27. Field D, Garrity G, Gray T, Morrison N, Selengut J, Sterk P, Tatusova T, Thomson N, Allen MJ, Angiuoli SV, Ashburner M, Axelrod N, Baldauf S, Ballard S, Boore J, Cochrane G, Cole J, Dawyndt P, De Vos P, DePamphilis C, 
Edwards R, Faruque N, Feldman R, Gilbert J, Gilna P, Glöckner FO, Goldstein P, Guralnick R, Haft D, Hancock D, Hermjakob H, Hertz-Fowler C, et al. The minimum information about a genome sequence (MIGS) specification. Nat Biotechnol. 2008; 26:541-47.

28. Joblin KN, Naylor GE, Williams AG. Effect of Methanobrevibacter smithii on xylanolytic activity of anaerobic ruminal fungi. Appl Environ Microbiol. 1990; 56:2287-95.

29. Widdel F, Kohring G, Mayer F. Studies on dissimilatory sulfate-reducing bacteria that decompose fatty acids III. Characterization of the filamentous gliding Desulfonema limicola gen. nov. sp. nov., and Desulfonema magnum sp. nov. Arch Microbiol. 1983; 134:286-94.

30. Tschech A, Pfennig N. Growth yield increase linked to caffeate reduction in Acetobacterium woodii. Arch Microbiol. 1984; 137:163-67.

31. Jarrell KF, Faguy D, Herbert AM, Kalmakoff ML. A general method of isolating high molecular weight DNA from methanogenic archaea (archaebacteria). Can J Microbiol. 1992; 38:65-8.

32. Staden R, Beal KF, Bonfield JK. The Staden package, 1998. Methods Mol Biol. 2000; 132:115-30.

33. Altermann E, Klaenhammer T. GAMOLA: a new local solution for sequence annotation and analyzing draft and finished prokaryotic genomes. OMICS. 2003; 7:161-69.

34. Rutherford K, Parkhill J, Crook J, Horsnell T, Rice P, Ranjandream MA, Barrell B. Artemis: sequence visualization and annotation. Bioinformatics. 2000; 16:944-45.

35. Delcher AL, Harmon D, Kasif S, White O, Salzberg S. Improved microbial gene identification with GLIMMER. Nucleic Acids Res. 1999; 27:4636-41.

36. Altschul SF, Gish W, Miller W, Myers E, Lipman D. Basic local alignment search tool. J Mol Biol. 1990; 215:403-10.

37. Gish W, States D. Identification of protein coding regions by database similarity search. Nat Genet. 1993; 3:266-72.

38. NCBI Resource Coordinators. Database resources of the National Center for Biotechnology Information. Nucleic Acids Res. 2013; 41:D8-D20.

39. Tatusov RL, Galperin M, Natale D, Koonin E. The COG database: a tool for genome-scale analysis of protein functions and evolution. Nucleic Acids Res. 2000; 28:33-6.

40. Eddy SR. Profile hidden Markov models. Bioinformatics. 1998; 14:755-63.

41. Punta M, Coggill PC, Eberhardt RY, Mistry J, Tate J, Boursnell C, Pang N, Forslund K, Ceric G, Clements J, Heger A, Holm L, Sonnhammer EL, Eddy SR, Bateman A, Finn RD. The Pfam protein families data-base. Nucleic Acids Res. 2012; 40:D290-301.

42. Haft DH, Selengut JD, Richter RA, Harkins D, Basu MK, Beck E. TIGRFAMs and genome properties in 2013. Nucleic Acids Res. 2013; 41:D387-95.

43. Krogh A, Larsson B, von Heijne G, Sonnhammer E. Predicting transmembrane protein topology with a hidden Markov model: application to complete genomes. J Mol Biol. 2001; 305:567-80.

44. http://www.cbs.dtu.dk/services /TMHMM/.

45. Petersen TN, Brunak S, von Heijne G, Nielsen H. SignalP 4.0: discriminating signal peptides from transmembrane regions. Nat Methods. 2011; 8:785-86.

46. Lowe TM, Eddy S. tRNAscan-SE: a program for improved detection of transfer RNA genes in genomic sequence. Nucleic Acids Res. 1997; 25:955-64.

47. Burge SW, Daub J, Eberhardt R, Tate J, Barquist L, Nawrocki EP, Eddy SR, Gardner PP, Bateman A. Rfam 11.0: 10 years of RNA families. Nucleic Acids Res. 2013; 41:D226-32

48. Eddy SR. A memory-efficient dynamic programing algorithm for optimal alignment of a sequence to an RNA secondary structure. BMC Bioinformatics. 2002; 3:18

49. Benson DA, Cavanaugh M, Clark K, Karsch-Mizrachi I, Lipman DJ, Ostell J, Sayers EW. GenBank. Nucleic Acids Res. 2013; 41:D36-42.

50. Helgadóttir S, Rosas-Sandoval G, Söll D, Graham DE. Biosynthesis of phosphoserine in the Methanococcales. J Bacteriol. 2007; 189:575-82.

51. Kandiba L, Eichler J. Analysis of putative nonulosonic acid biosynthesis pathways in Archaea reveals a complex evolutionary history. FEMS Microbiol Lett. 2013; 345:110-20.

52. Lo C, Bonner CA, Xie G, D'Souza M, Jensen RA. Cohesion group approach for evolutionary analysis of aspartokinase, an enzyme that feeds a branched network of many biochemical pathways. Microbiol Mol Biol Rev. 2009; 73:594-651.

53. Moe WM, Yan J, Nobre MF, da Costa MS, Rainey FA. Dehalogenimonas lykanthroporepellens gen. nov., sp. nov., a reductively dehalogenating bacterium isolated from chlorinated solvent-contaminated groundwater. Int J Syst Evol Microbiol. 2009; 59:2692-97.
54. Taylor BL, Zhulin IB. PAS domains: internal sensors of oxygen, redox potential, and light. Microbiol Mol Biol Rev. 1999; 63:479-506.

55. Magingo FSS, Stumm CK. Nitrogen fixation by Methanobacterium formicicum. FEMS Microbiol Lett. 1991; 81:273-78.

56. Lie TJ, Hendrickson EL, Niess UM, Moore BC, Haydock AK, Leigh JA Overlapping repressor binding sites regulate expression of the Methanococcus maripaludis glnK 1 operon. Mol Microbiol. 2010; 75:755-62.

57. Gutiérrez G. Draft genome sequence of Methanobacterium formicicum DSM 3637, an archaebacterium isolated from the methane producer amoeba Pelomyxa palustris. J Bacteriol. 2012; 194:6967-68.

58. Rosewarne CP, Greenfield P, Li D, Tran-Dinh N, Midgley DJ, Hendry P. Draft genome sequence of Methanobacterium sp. Maddingley, reconstructed from metagenomic sequencing of a methanogenic microbial consortium enriched from coal-seam gas formation water. Genome Announc. 2013; 1:e00082-12.

59. Cadillo-Quiroz H, Bräuer SL, Goodson N, Yavitt JB, Zinder SH. Methanobacterium paludis sp. nov. and a novel strain of Methanobacterium lacus isolated from northern peatlands. Int J Syst Evol Microbiol. 2014; 64:1473-80.

60. Maus I, Wibberg D, Stantscheff R, Cibis K, Eikmeyer F-G, König H, Pühler A, Schlüter A. Complete genome sequence of the hydrogenotrophic archaeon Methanobacterium sp. Mb1 isolated from a production-scale biogas plant. J Biotechnol. 2013; 168:734-36.

61. Li L, Stoeckert CJ Jr, Roos DS. OrthoMCL: identification of ortholog groups for eukaryotic genomes. Genome Res. 2003; 13:2178-89.

doi:10.1186/1944-3277-9-15

Cite this article as: Kelly et al:: The complete genome sequence of the rumen methanogen Methanobacterium formicicum BRM9. Standards in Genomic Sciences 2014 9:15.

\section{Submit your next manuscript to BioMed Central and take full advantage of:}

- Convenient online submission

- Thorough peer review

- No space constraints or color figure charges

- Immediate publication on acceptance

- Inclusion in PubMed, CAS, Scopus and Google Scholar

- Research which is freely available for redistribution

Submit your manuscript at www.biomedcentral.com/submit
C Biomed Central 